\title{
PENERAPAN METODE SCAFFOLDING UNTUK MENINGKATKAN PRESTASI BELAJAR SISWA PADA PEMBELAJARAN PENJAS
}

\author{
Didin Jaenudin \\ SMP Negeri I Lemahabang Cirebon, Indonesia \\ didinjaenudin@gmail.com
}

\begin{abstract}
Physical education is basically an integral part of the overall education system. The purpose of physical education is not only to develop the physical sphere, but also to develop aspects of health, physical fitness, critical thinking skills, emotional stability, social skills, reasoning and moral action through physical activities and sports activities. But problems arise when students are not aware of the importance of physical education in their lives. This has an impact on the low learning achievement in physical education subjects. The author tries to use the scaffolding method as a solution to these problems and is set forth in a study, because this method encourages students to learn independently. This research is a classroom action research conducted to solve learning problems in class. The research subject was the place used in this study were students of class VII-H of SMP Negeri I Lemababang Cirebon Regency in 2019/2020 Academic Year as many as 30 students on Volleyball game material. Based on the results of the study, the scaffolding method in learning Volleyball games has a positive impact in improving student achievement. This improvement is shown by the increase in students' learning completeness in each cycle, namely pre-cycle (36\%), cycle I (60\%), cycle II (96\%). Thus concluded, the scaffolding method can improve student achievement in physical education learning.
\end{abstract}

Keywords: Scaffolding method, learning achievement, physical education.

\section{ABSTRAK}

Pendidikan jasmani pada dasarnya merupakan bagian integral dari sistem pendidikan secara keseluruhan. Tujuan pendidikan jasmani bukan hanya mengembangkan ranah jasmani, tetapi juga mengembangkan aspek kesehatan, kebugaran jasmani, keterampilan berpikir kritis, stabilitas emosional, keterampilan sosial, penalaran dan tindakan moral melalui kegiatan aktivitas jasmani dan olah raga. Namun permasalahan muncul ketika siswa belum menyadari akan pentingnya pendidikan jasmani pada kehidupan mereka. Hal ini berdampak pada rendahnya prestasi belajar pada mata pelajaran pendidikan jasmani. Penulis mencoba menggunakan metode scaffolding sebagai solusi dari permasalahan tersebut dan dituangkan dalam sebuah penelitian, karena metode ini mendorong siswa untuk belajar mandiri. Penelitian ini merupakan penelitian tindakan kelas yang dilakukan untuk memecahkan masalah pembelajaran di kelas. Subyek penelitian adalah tempat yang digunakan dalam penelitian ini adalah siswa kelas VIIH SMP Negeri I Lemahabang Kabupaten Cirebon Tahun Pelajaran 2019/2020 sebanyak 30 siswa pada materi permainan Bola Voli. Berdasarkan hasil penelitian, metode scaffolding dalam pembelajaran permainan Bola Voli berdampak positif dalam meningkatkan prestasi belajar siswa. Peningkatan tersebut ditunjukkan dengan peningkatan ketuntasan belajar siswa dalam setiap siklus, yaitu prasiklus (36\%), siklus I (60\%), siklus II (96\%). Dengan demikian disimpulkan, metode scaffolding dapat meningkatkan prestasi belajar siswa pada pembelajaran pendidikan jasmani.

Kata Kunci: Metode Scaffolding, prestasi belajar, pembelajaran penjas.

Submitted December 3, 2019 | Revised December 6, 2019 | Accepted December 11, 2019

\section{Pendahuluan}

Pendidikan jasmani pada dasarnya merupakan bagian integral dari sistem pendidikan secara keseluruhan. Oleh karena itu, pelaksanaan pendidikan jasmani harus diarahkan pada pencapaian tujuan tersebut. Tujuan pendidikan jasmani bukan hanya mengembangkan ranah jasmani, tetapi juga mengembangkan aspek kesehatan, kebugaran jasmani, keterampilan berfikir kritis, stabilitas emosional, keterampilan sosial, penalaran dan tindakan moral melalui kegiatan 
aktivitas jasmani dan olah raga. Pendidikan jasmani merupakan media untuk mendorong perkembangan motorik, kemampuan fisik, pengetahuan dan penalaran, penghayatan nilai-nilai (sikap-mental-emosional-spritual-dan sosial), serta pembiasan pola hidup sehat yang bermuara untuk merangsang pertumbuhan dan perkembangan yang seimbang.

Pendidikan jasmani memiliki peran yang sangat penting dalam mengintensifkan penyelenggaraan pendidikan sebagai suatu proses pembinaan manusia yang berlangsung seumur hidup. Pendidikan jasmani memberikan kesempatan pada siswa untuk terlibat langsung dalam aneka pengalaman belajar melalui aktivitas jasmani, bermain, dan berolahraga yang dilakukan secara sistematis, terarah dan terencana. Pembekalan pengalaman belajar itu diarahkan untuk membina, sekaligus membentuk gaya hidup sehat dan aktif sepanjang hayat.

Dalam proses pembelajaran pendidikan jasmani guru harus dapat mengajarkan berbagai keterampilan gerak dasar, teknik dan strategi permainan / olahraga, internalisasi nilai-nilai (sportifitas, jujur kerjasama, dan lain-lain) dari pembiasaan pola hidup sehat. Pelaksanaannya bukan melalui pengajaran konvensional di dalam kelas yang bersifat kajian teoritis, namun melibatkan unsur fisik mental, intelektual, emosional dan sosial. Aktivitas yang diberikan dalam pengajaran harus mendapatkan sentuhan dikdakdik-metodik, sehingga aktivitas yang dilakukan dapat mencapai tujuan pengajaran. Melalui pendidikan jasmani diharapkan siswa dapat memperoleh berbagai pengalaman untuk mengungkapkan kesan pribadi yang menyenangkan, kreatif, inovatif, terampil, meningkatkan dan memeliharan kesegaran jasmani serta pemahaman terhadap gerak manusia.

Namun kenyataan di lapangan siswa belum menyadari akan pentingnya pendidikan jasmani pada kehidupan mereka. Hal ini berdampak pada rendahnya prestasi belajar pada mata pelajaran pendidikan jasmani. Untuk itu guru harus mampu mengembangkan pembelajaran yang efektif, disamping harus memahami dan memperhatikan karakteristik dan kebutuhan siswa. Pada masa usia tersebut seluruh aspek perkembangan manusia baik itu kognitif, psikomotorik dan afektif mengalami perubahan. Agar standar kompetensi pembelajaran pendidikan jasmani dapat terlaksana sesuai dengan pedoman, maksud dan juga tujuan sebagaimana yang ada dalam kurikulum, maka guru pendidikan jasmani harus mampu membuat pembelajaran yang efektif dan menyenangkan. Untuk itu perlu adanya pendekatan, variasi maupun modifikasi dalam pembelajaran. Ketidaktepatan dalam memilih model pembelajaran yang sesuai dengan pokok bahasan yang akan dipelajari,menyebabkan timbulnya berbagai masalah seperti belum dapat mengajukan permasalahan untuk dijadikan bahan pembelajaran, tidak dapat mengorganisir tugas belajar yang berhubungan suatu masalah, dan masih kesulitan dalam melakukan penyelidikan, serta belum mampu mengembangkan dan menganalisis hasil pembelajarannya. Kondisi ini terjadi juga pada siswa kelas VII-H SMP Negeri I Lemahabang Kabupaten Cirebon, di mana ketuntasan belajar pada mata pelajaran pendidikan jasmani masih rendah. Hal ini terlihat dari ketuntasan siswa pada mata pelajaran ini hanya 64\%. Atas dasar itulah guru dituntut untuk melakukan berbagai upaya mengatasi permasalahan tersbut. Salah satu upaya yang dapat dilakukan adalah menentukan metode pembelajaran yang tepat dan relevan, salah satunya adalah metode scaffolding. Penerapan pembelajaran yang memungkinkan dapat memberikan kondisi belajar siswa aktif adalah dengan pembelajaran melalui penerapan Scaffolding. Pembelajaran Scaffolding 
diartikan sebagai suatu teknik pemberian dukungan belajar, yang dilakukan pada tahap awal untuk mendorong siswa agar dapat belajar secara mandiri (Nurhayati, 2017).

Scaffolding pertama kali diperkenalkan oleh Wood, Bruner, dan Ross (dalam Jalmo, 2009), merupakan proses meningkatkan kemampuan siswa atau orang yang baru dalam memecahkan masalah atau mencapai tujuan di luar dari kemampuan dirinya. Vygotsky mendefinisikan scaffolding sebagai "peran guru dan lainnya dalam membantu perkembangan siswa dan pemberian dukungan terstruktur untuk mencapai tahap atau tingkat berikutnya. Jika bantuan yang diberikan tidak berhubungan dengan kompetensi tersebut maka tidak dapat dikatakan sebagai scaffolding. Scaffolding dilandasi dari teori sosiokultural Vygotsky, yaitu bahwa interaksi social memainkan peran yang mendasar dalam perkembangan kognisi. Belajar terjadi melalui partisipasi siswa dalam pengalaman-pengalaman social dan kultural yang sengaja ditanamkan.

Adinegara (2010) mengemukakan, ide penting lain yang diturunkan dari Vygotsky adalah scaffolding. Scaffolding berarti memberikan sejumlah besar bantuan kepada seorang anak selama tahap-tahap awal pembelajaran kemudian anak tersebut mengambil alih tangung jaawab yang semakin besar segera setelah ia dapat melakukannya. Bantuan tersebut dapat berupa petunjuk, peringatan, dorongan, menguraikan masalah kedalam langkah-langkah pembelajaran, memberikan contoh ataupun yang lain sehinggga memungkinkan siswa tumbuh mandiri. Vygotsky (dalam Vlamband, 2008) mencari pengertian bagaimana anak-anak berkembang dengan melalui proses belajar, dimana fungsi-fungsi kognitif belum matang, tetapi masih dalam proses pematangan. Vygotsky membedakan antara aktual development dan potensial development pada anak. Aktual development ditentukan apakah seorang anak dapat melakukan sesuatu tanpa bantuan orang dewasa atau guru. Sedangkan potensial development membedakan apakah seorang anak dapat melakukan sesuatu, memecahkan masalah di bawah petunjuk orang dewasa atau kerjasama dengan teman sebaya.

Dalam proses scaffolding, pengajar membantu memberikan pemahaman dalam menyelesaikan tugas atau konsep-konsep yang sulit bagi para pemelajar. Pengajar hanya membantu pemelajar dengan memberikan arahan atau media dalam mengerjakan tugas-tugas yang sulit dikuasai pemelajar, namun tanggung jawab penyelesaian tugas tetap pada diri pemelajar (Zamahsari, 2019). Menurut Wood, Bruner \& Ross, Scaffolding dideksripsikan sebagai bantuan yang diberikan kepada peserta didik oleh orang yang memiliki pengetahuan lebih seperti guru atau teman sebaya dalam menyelesaikan tugas yang tidak mampu dilaksanakannya (Nabila, dkk. 2019).

Di sisi lain, Lipscomb et al (2004) mengungkapkan terdapat sembilan keuntungan dari proses pembelajaran menggunakan scaffolding, yaitu: (1) dapat mengidentifikasi bakat dan tingkat kemampuan siswa seawall mungkin, (2) memberikan pembelajaran secara individual, (3) memberikan jaminan yang lebih besar dalam pencapaian pemahaman yang komprehensip, (4) memberikan pengalaman belajar yang variatif, (5) meningkatkan efesiensi pembelajaran, (6) menciptakan percepatan melalui pemberian bimbingan secara terstruktur, (7) membuat siswa berpartisifasi aktif dalam proses pembelajaran, (8) mendorong dan memotivasi siswa untuk belajar, dan (9) meminimalkan tingkat keputusasaan siswa dalam belajar. 


\section{Metode Penelitian}

Penelitian ini merupakan Penelitian Tindakan Sekolah yang dilakukan secara kolaborasi. Penelitian Tindakan Sekolah berdasarkan pendapat Sanjaya (2011: 26) adalah proses pengkajian masalah pembelajaran di dalam kelas melalui refleksi diri dalam upaya untuk memecahkan masalah tersebut dengan cara melakukan tindakan yang terencana dalam situasi nyata serta menganalisis setiap pengaruh dari perlakuan tersebut. Pendapat tersebut sesuai pendapat yang disampaikan oleh Kasbolah (2001: 15), bahwa Penelitian Tindakan Sekolah merupakan penelitian tindakan dalam bidang pendidikan yang dilaksananakan dalam kawasan kelas dengan tujuan untuk memperbaiki dan atau meningkatkan kualitas pembelajaran.

Banyak model Penelitian Tindakan Sekolah yang dapat diterapkan, tetapi dalam penelitian ini menggunakan model Kemmis dan McTaggart di mana dalam perencanaannya menggunakan siklus sistem spiral yang di dalamnya terdiri dari empat komponen, yaitu rencana, tindakan dan observasi serta refleksi (Sujati, 2000: 23).

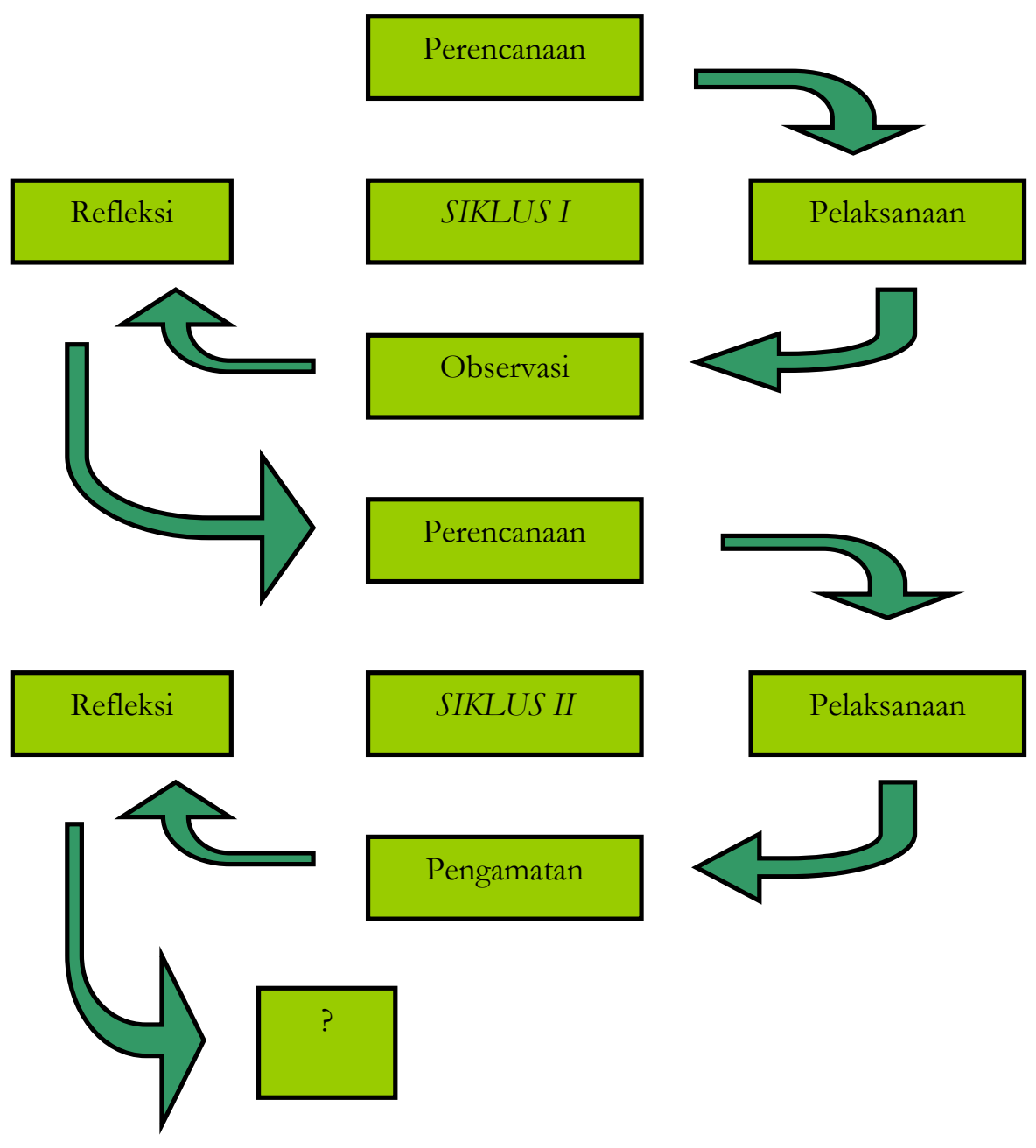

Gambar 1. Model kemmis dan Mc Taggart 
Perencanaan, sebelum mengadakan penelitian peneliti menyusun rumusan masalah, tujuan dan membuat rencana tindakan, termasuk di dalamnya instrumen penelitian dan RPP. Pelaksanaan tindakan dan pengamatan dilakukan dengan meliputi tindakan yang dilakukan oleh guru sebagai upaya membangun pemahaman konsep siswa serta mengamati hasil atau dampak dari diterapkannya model Pembelajaran. Refleksi, yakni berupa kajian hasil atau dari tindakan yang dilakukan berdasarkan lembar observasi (LO) yang diisi oleh onbserver (Arikunto, 2008).

Penelitian dilaksanakan di SMP Negeri I Lemahabang Kabupaten Cirebon Tahun Pelajaran 2019/2020 dengan Subyek penelitian adalah siswa-siswi Kelas VII H VII-H SMP Negeri I Lemahabang Kabupaten Cirebon Tahun Pelajaran 2019/2020. Sebanyak 30 siswa. Penelitian dilaksanakan pada bulan September semester ganjil 2019/2020.

Data penelitian yang dikumpulkan berupa data observasi berupa pengamatan pengelolaan model pembelajaran dan pengamatan aktivitas siswa dan guru pada akhir pembelajaran, dan data tes formatif siswa pada setiap siklus. Data lembar observasi diambil dari dua pengamatan yaitu data model pembelajaran Scaffolding yang digunakan untuk mengetahui pengaruh penerapan model pembelajaran Scaffolding dalam meningkatkan aktivitas belajar. Data tes formatif untuk mengetahui peningkatan prestasi belajar siswa setelah diterapkan model pembelajaran

\section{Hasil dan Pembahasan}

\section{Siklus 1}

Tahap perencanaan pada siklus 1, penulis mempersiapkan perangkat pembelajaran yang terdiri dari rencana pelajaran 1, LKS 1, soal tes formatif 1, dan alat-alat pengajaran yang mendukung.

Pelaksanaan pada siklus 1, kegiatan belajar mengajar untuk siklus I dilaksanakan pada Harin Sabtu tanggal 14 -9-2019 VII-H SMP Negeri I Lemahabang Kabupaten Cirebon Tahun Pelajaran 2019/2020. dengan jumlah siswa 30 siswa.Dalam hal ini peneliti bertindak sebagai guru. Adapun proses belajar mengajar mengacu pada rencana pelajaran dengan memperhatikan revisi pada prasiklus, sehingga kesalahan atau kekurangan pada prasiklus tidak terulang lagi pada siklus I.Pengamatan (observasi) dilaksanakan bersamaan dengan pelaksanaan belajar mengajar.

Pada akhir proses belajar mengajar siswa diberi tes formatif II dengan tujuan untuk mengetahui tingkat keberhasilan siswa selama proses belajar mengajar yang telah dilakukan. Instrument yang digunakan adalah tes formatif II. Adapun data hasil penelitian pada siklus I adalah sebagai berikut

Tabel 1. Rekapitulasi Hasil Tes Formatif Siswa Siklus 1

\begin{tabular}{cll}
\hline No & Uraian & Hasil Siklus II \\
\hline 1 & Nilai rata-rata tes formatif & 70.00 \\
2 & Jumlah siswa yang tuntas belajar & 18 \\
3 & Persentase ketuntasan belajar & $60 \%$ \\
\hline
\end{tabular}

Dari tabel di atas diperoleh nilai rata-rata prestasi belajar siswa adalah 70.00 dan ketuntasan belajar mencapai $60 \%$ atau ada 18 siswa dari 30 siswa sudah tuntas belajar. Hasil ini menunjukkan bahwa pada siklus I ini ketuntasan belajar secara klasikal telah mengalami peningkatan sedikit 
lebih baik dari prasiklus.Adanya peningkatan hasil belajar siswa ini karena setelah guru menginformasikan bahwa setiap akhir pelajaran akan selalu diadakan tes sehingga pada pertemuan berikutnya siswa lebih termotivasi untuk belajar. Selain itu siswa juga sudah mulai mengerti apa yang dimaksudkan dan diinginkan guru dengan menerapkan model pembelajaran.

2. Siklus 2

Tahap perencanaan pada siklus 2, penulis mempersiapkan perangkat pembelajaran yang terdiri dari rencana pelajaran 3, LKS 3, soal tes formatif 3, dan alat-alat pengajaran yang mendukung.

Pada siklus 2, Pelaksanaan kegiatan belajar mengajar untuk siklus II dilaksanakan pada Hari Sabtu tanggal 21-9-2017 di Kelas VII H SMP Negeri 1 Lemahabang Kabupaten Cirebon Tahun Pelajaran 2019/2020. dengan jumlah siswa 30 siswa. Dalam hal ini peneliti bertindak sebagai guru. Adapun proses belajar mengajar mengacu pada rencana pelajaran dengan memperhatikan revisi pada siklus II, sehingga kesalahan atau kekurangan pada siklus I tidak terulang lagi pada siklus II.Pengamatan(observasi) dilaksanakan bersamaan dengan pelaksanaan belajar mengajar.

Pada akhir proses belajar mengajar siswa diberi tes formatif III dengan tujuan untuk mengetahui tingkat keberhasilan siswa dalam proses belajar mengajar yang telah dilakukan. Instrumen yang digunakan adalah tes formatif III. Adapun data hasil peneitian pada siklus II adalah sebagai berikut

Tabel 1. Rekapitulasi Hasil Tes Formatif Siswa Siklus 1

\begin{tabular}{clc}
\hline No & Uraian & Hasil Siklus II \\
\hline 1 & Nilai rata-rata tes formatif & 83.87 \\
2 & Jumlah siswa yang tuntas belajar & 29 \\
3 & Persentase ketuntasan belajar & $96 \%$ \\
\hline
\end{tabular}

Berdasarkan tabel diatas diperoleh nilai rata-rata tes formatif sebesar 83.87 dan dari 30 siswa yang telah tuntas sebanyak 29 siswa mencapai ketuntasan belajar. Maka secara klasikal ketuntasan belajar yang telah tercapai sebesar 96\% (termasuk kategori tuntas). Hasil pada siklus II ini mengalami peningkatan lebih baik dari siklus I. Adanya peningkatan hasil belajar pada siklus II ini dipengaruhi oleh adanya peningkatan kemampuan guru dalam menerapkan model pembelajaran Scaffolding sehingga siswa menjadi lebih terbiasa dengan pembelajaran seperti ini sehingga siswa lebih mudah dalam memahami materi yang telah diberikan. Pada siklus II ini ketuntasan secara klasikal telah tercapai, sehingga penelitian ini hanya sampai pada siklus II.

Berdasarkan hasil penelitian yang dilaksanakan pada siklus 1 dan 2, diperoleh beberapa temuan sebagai berikut:

a) Selama proses belajar mengajar guru telah melaksanakan semua pembelajaran dengan baik. Meskipun ada beberapa aspek yang belum sempurna, tetapi persentase pelaksanaannya untuk masing-masing aspek cukup besar.

b) Berdasarkan data hasil pengamatan diketahui bahwa siswa aktif selama proses belajar berlangsung.

c) Kekurangan pada siklus-siklus sebelumnya sudah mengalami perbaikan dan peningkatan sehingga menjadi lebih baik.

d) Hasil belajar siswa pada siklus II mencapai ketuntasan. 
Pada siklus II guru telah menerapkan model pembelajaran Scaffolding dengan baik dan dilihat dari aktivitas siswa serta hasil belajar siswa pelaksanaan proses belajar mengajar sudah berjalan dengan baik. Maka tidak diperlukan revisi terlalu banyak, tetapi yang perlu diperhatikan untuk tindakan selanjutnya adalah memaksimalkan dan mepertahankan apa yang telah ada dengan tujuan agar pada pelaksanaan proses belajar mengajar selanjutnya penerapan model pembelajaran pemberian tugas belajar dan resitasi dapat meningkatkan proses belajar mengajar sehingga tujuan pembelajaran dapat tercapai.

\section{Kesimpulan}

Dari hasil kegiatan pembelajaran yang telah dilakukan selama tiga siklus, dan berdasarkan seluruh pembahasan serta analisis yang telah dilakukan dapat disimpulkan sebagai berikut:

1. Pembelajaran permainan Bola Voli dengan memiliki dampak positif dalam meningkatkan prestasi belajar siswa yang ditandai dengan peningkatan ketuntasan belajar siswa dalam setiap siklus, yaitu prasiklus (36\%), siklus I (60\%), siklus II (96\%).

2. Penerapan model pembelajaran naik turun tangga mempunyai pengaruh positif, yaitu dapat meningkatkan motivasi belajar siswa yang ditunjukan dengan hasil wawancara dengan sebagian siswa, rata-rata jawaban siswa menyatakan bahwa siswa tertarik dan berminat dengan model pembelajaran model sehingga mereka menjadi termotivasi untuk belajar.

\section{Daftar Pustaka}

Adinegara. (2010). Vygotskian Perspective: Proses Scaffolding untuk mencapai Zone of Proximal Development (ZPD). [Online] Tersedia : http://dlog.Unnes.ac.id/adinegara/2010/03/04/vygotskianperspective-prosesscaffolding-untuk-mencapai-zone-of-proximal-developmentzpd/

Arikunto, S.. (2008). Penelitian Tindakan Kelas, PT. Bumi Aksara, Jakarta.

Jalmo. (2009). Perencanaan Test. UPI. Bandung.

Kasbolah, K. (2001). Penelitian Tindakan Kelas (PTK). Malang: Depdikbud.

Lipscomb, L., Swason, J. \& Anne, W. (2004). Scaffolding: From emerging perspective on learning. Teaching and Teachnology.

Nabila, dkk. (2017). Pengaruh Penerapan Strategi Scaffolding Terhadap Ketuntasan Hasil Belajar Peserta Didik SMA Negeri 4 Banda Aceh Pada Submateri Tata Nama Senyawa Hidrokarbon. Pendidikan Sains Pascasarjana Universitas Negeri Surabaya. Vol. 6 (2) hal 13101316.

Nurhayati, E. (2017). Penerapan scaffolding untuk pencapaian kemandirian belajar siswa. Jurnal Penelitian Pendidikan dan Pengajaran Matematika. Vol. 3 no. 1, hal. 21-26.

Sanjaya, W. (2011). Penelitian Tindakan Kelas. Jakarta: Kencana Prenada. Media Grup.

Sujati. (2000). Penelitian Tindaka Kelas. Yogyakarta. FIP. UNY 
Vlamband. (2008). Teori Perkembangan Kognitif Vygotsky. [Online]. Tersedia : http;//valmband.multipl.com/journal/item/11/TEORI_PERKEMBANGAN_KOGNITI F_VYGOTSKY.

Zamahsari, dkk. (2019). Implementasi Scaffolding dalam Pembelajaran BIPA di Kelas Pemula. Jurnal Pendidikan, Vol. 4 (1), hal 68-78. 